\title{
GIFTED: THE MONOLINGUALISM OF CORPORATE SOCIAL RESPONSIBILITY
}

\author{
GIFTED: O MONOLINGUISMO DA RESPONSABILIDADE SOCIAL CORPORATIVA
} GIFTED: EL MONOLINGÜISMO DE LA RESPONSABILIDAD SOCIAL CORPORATIVA

\begin{abstract}
Acts of Corporate Social Responsibility are more often than not portrayed as success-story narratives. A quasi-ethnographic study in Senegal shatters the underlying assumptions of these accounts. First a computer donation from a Northern country is described with all the usual incidents and related vocabulary. Later, during a visit to a Senegalese rubbish dump, the story starts to falter, as countless questions arise about what is actually going on there, and how we can know and represent it (both as a portrayal and as a voice). A tipping point in an interview serves to
\end{abstract}

reveal the ambiguities of the position adopted and the difficulties of expressing oneself in a different language. The CSR language is described as a kind of monolingualism, which employs a particular vocabulary and grammar for what is said or thought. This is the monolingualism of the other. Some of the implications of this monolingualism are examined, and this leads to the conclusion that there is a need to take measures with regard to the CSR language and that more than one language is needed to speak about CSR.

KEYWORDS Corporate social responsibility, digital solidarity, monolingualism, donation, ethnography of CSR

Jean-Luc Moriceau jean-luc.moriceau@it-sudparis.eu

Professor at Institut Telecom, Telecom Ecole de Management Research/Organization Studies - Paris, France

Geraldine Guerillot geraldineguerillot@yahoo.fr

PhD Student in Management Science, Institut Telecom, Telecom Ecole de Management Research - Paris, France

Resumo Ações de Responsabilidade Social Corporativa são normalmente retratadas como narrativas de histórias de sucesso. Um estudo quasi-etnográfico no Senegal fornece a oportunidade para questionar isso. Primeiro, uma doação de computadores de um país do norte é descrita com o enredo e vocabulário usuais. Posteriormente, uma visita ao depósito de lixo senegalês faz esta história balbuciar e levanta questões sobre o que lá acontece e como podemos conhecer e representa-lo (tanto como representação, quanto como voz). Um momento significativo em uma entrevista revela as ambiguidades de posicionamentos e as dificuldades de se expressar em outra linguagem. A linguagem RSC é descrita como um monolinguismo, impondo vocabulário e gramática para o que é dito e pensado. Este é um monolinguismo do outro (um sendo monolinguismo do outro). Algumas conseqüências de tal monolinguismo são examinadas, concluindo que há uma necessidade de ação quanto a essa linguagem única. Mais de uma linguagem é necessária para falar sobre RSC.

Palavras-chave Responsabilidade social corporativa, solidariedade digital, monolinguismo, doação, etnografia da RSE.

Resumen Acciones de RSC -Responsabilidad Social Corporativa- son normalmente retratadas como narrativas de historias de éxito. Un estudio cuasietnográfico en Senegal proporciona la oportunidad para cuestionar eso. Primero, una donación de computadoras de un país del norte es descripta con el argumento y vocabulario usuales. Posteriormente, una visita al depósito de basura senegalés hace esta historia balbucear y levanta cuestiones sobre 10 que allí sucede y cómo podemos conocer y representarlo (tanto como representación, cuanto como voz). Un momento significativo en una entrevista revela las ambigüedades de posicionamientos y las dificultades de expresarse en otro lenguaje. El lenguaje RSC es descripto como un monolingüismo, imponiendo vocabulario y gramática para lo que es dicho y pensado. Este es un monolingüismo del otro (uno siendo monolingüismo del otro). Algunas consecuencias de tal monolingüismo son examinadas, concluyendo que hay una necesidad de acción respecto a ese lenguaje único. Más de un lenguaje es necesario para hablar sobre RSC.

Palabras clave Responsabilidad social corporativa, solidaridad digital, monolingüismo, donación, etnografía de la RSC. 


\section{INTRODUGTION}

According to the current political and managerial discourse, sustainability, CSR and digital solidarity can be acclaimed as normative practices for the good of Southern countries. Who could challenge such a generous supposition? Yet there are some voices that do question what seems indisputably desirable. Sustainable development reflects the elitist standpoint of rich countries on environmental issues with a unilateral overemphasis on free markets, population growth and the survival of endangered species (DOYLE, 1998). Globalization and global governance can be described as a process in which one world imposes its worldview on others (DERRIDA, 2002; SOLE, 2000). Corporate social responsibility, in the way in which it has been institutionalized, claims to have a concern for Southern countries, their workers and inhabitants, but then proceeds to transform them into "faceless figures", thus avoiding questions of responsibility (MORICEAU, 2005; MARENS, 2010). In effect, it enables corporations to boast of their achievements in numerical terms but falls desperately short with regard to (digital) solidarity and (social) responsibility.

Recently, several studies have drawn attention to the role of institutional factors that either explain or affect the spread of CSR among countries, by providing conceptual frameworks (AGUILERA and others, 2007; CAMPBELL, 2007; MATTEN and MOON, 2008) or case studies (e.g. WAILES, MICHELSON, 2009). However, we still know very little about where exactly, and to what extent, the CSR discourses pervade the practices and discourses found in Southern countries. CSR discourses may be conceived of as a form of "epistemic imperialism", as postulated by Spivak (1988), which compels Southern subjects to define themselves as the objects of philanthropy who have been given Western models to imitate. Since the CSR discourses have certain effects, we need to know more about what is not stated, and what cannot be stated, in the numerous CSR (success) stories.

More precisely, is there not a monolingualism linked to CSR, that forces Southern countries to speak the language of the other world? Is it not the case that donations to such countries constitute more than just material aid? How can one account for the effects of digital solidarity donations outside the language of CSR?

Take the case of the gift of a large computer from a French company to Senegal; one wonders whether this kind of donation can be accounted for outside the frames and language of CSR. Moreover, by raising this question, we can have a better understanding of the role that narrative and language play in CSR postcolonial development aid.

First of all, the concepts of sustainability, CSR and digital solidarity will be briefly reviewed. This will be followed by an explanation of the choice of a quasiethnographic approach, with an emphasis on affects and reflexivity, as advocated by Stewart (1996). The case, as a success story, will then be briefly examined, before two moving and significant incidents are described: namely a visit to a rubbish dump and an interview with the project manager of a national e-waste program. In both cases, the way in which things just happen and feelings can suddenly rise to the surface will become potently obvious. There will then be a discussion that lays stress on how monological and incomplete the language of CSR is; the implications of this will be sketched out, together with recommendations for further research into this particular language and type of narrative.

\section{CSR and digital solidarity}

Sustainable development is a much debated and highly controversial concept. Its most famous definition occurs in the Brundtland report: "[...] a development that meets the needs of the present without compromising the ability of future generations to meet their own needs" (BRUNDTLAND, 1989). Various strategies and discourses are involved, especially with regard to the North-South divide. For example, the developing countries were initially opposed to the use of the expression "sustainable development" at the Rio conference, because they were apprehensive that the concept might be an instrument directed against their economic development (BRUNEL, 2005). However, the Southern Countries had to turn to 'Green' diplomacy "for fear of losing their sovereignty and to have access to international credits" (idem). They would not hesitate to implement a sustainable development imposed on them if it were to their advantage (MANCEBO, 2007).

Corporate social responsibility (CSR) is far less debated and in most accounts, is usually portrayed as a success [-] story. CSR refers to measures (e.g. donations) taken by companies, that go beyond their legal obligations and short term interests, and as a result of which, they claim they are making a contribution 
to sustainable development and digital solidarity. Its long history stretches back to the charitable aid of the Middle Ages, the moralising paternalism of the early $20^{\text {th }}$ Century, and the religiously influenced corporate responsibility of the 1960s business man (PESQUEUX, 2010). It has been firmly grounded in economic theory involving a stakeholder approach of the firm (FREEMAN, 1984) and increasingly become a widespread, influential practice and discourse. Recently, CSR has advanced one step further to imposing its one language as the ISO 26000 standard. Any organization and public policymaking strategy is invited to adhere to these worldwide guidelines for governance. Although CSR is now a much acclaimed practice, some researchers criticize the way it is used by companies. For example, Pesqueux (2005) complains that its utopian nature, which used to adopt a critical stance with regard to practice, has now allowed it to play a more ideological, legitimizing role. Paula Soares (2004) shows the unstated contradictory aspects of some of its projects, while Schroeder and Schroeder (2004) reveal that CSR is employing hidden strategies to gain more power. However, what is still lacking are alternative or post-colonial voices that can provide a first-hand description of how CSR is experienced and help to shape a very particular kind of subject.

This study will focus on CSR projects that involve digital solidarity activities. In concrete terms, this solidarity takes the form of sending consignments of used computers from the North to countries in the South so that they too can participate in the global information society. Digital solidarity is of special interest because it obviously puts Southern countries in a double-bind situation. International discourses on sustainable development call for curbs on consumption and an encouragement of recycling or the proper disposal of digital waste. At first sight, extending the life of electronic equipment when the ecological footprint method is employed in a large part of the manufacturing process, seems to be good for the environment. However the discourse aimed at eradicating digital divides puts pressure on the technological world to make new information and communication technologies generally available, and is regarded as an important tool (UNCTAD, 2008) that is conditionally necessary for development. Thus injunctions from the North are ambivalent and paradoxical: "develop in digital technology / reduce your digital waste!" and very often, "accept our used digital products (sometimes already waste) / don't create digital waste." The double-bind situation is insoluble because one cannot satisfy such an ambivalent injunction. In individual situations, a double-bind often leads to a pathological reaction (BATESON, 1972; WATZLAWICK and others, 1967). The reactions to such paradoxical injunctions, the way they were expressed and other narratives (which differed from the "heroic" CSR stories) comprise the focal point of this inquiry.

\section{A quasi-ethnographic, affective approach}

How can I reach out to those who are all too familiar with our discourse on CSR and listen to their voices? How can one attempt to escape from the suspected monolingualism? Above all, how is it possible to avoid the arrogant and neocolonial attitudes of the Northerners towards the South? In view of this, I decided to turn to subjective, vulnerable and reflective voices, rather than rely on questionnaires or just direct questioning. In my approach, I did not want to hide behind numbers, avoid face-to-face encounters or act on the supposition that there is only one single world that is uniform. That is why I followed the path of K. Stewart (1996, 2009) who sought to study the effects and experiences of neo-liberalism, advanced capitalism, and globalization, while not remaining stuck in such grandiose words. Stewart was in search of moving things: "things that are in motion and that are defined by their capacity to affect and to be affected - they have to be mapped through different, coexisting forms of composition, habituation, and event" (2009, p.4).

I endeavored to travel from North to South, to the places of power and misery and allow myself to be affected. I wished to cleanse myself of the slogans that captivate us and threaten to petrify our ideas, so that I could begin to feel, hear and see with my five senses, and thus distance myself from too familiar stories and pre-constrained narratives. It was necessary to be in contact with many voices and multiple narratives, which do not fall into the creed of CSR, and its systematic and balanced criticism. I was prepared for a "clash of epistemologies" (STEWART, 1996, p.5), when I attempted to reopen the gaps in the concept of CSR, to allow other languages and senses to arouse and broaden our understanding.

The crisis of representation which ethnography has faced, resonates with the concerns put forward in this paper. Since the mid-80s, questions have been posed about the possibility of the ethnographer being able to represent the "other" (both in terms of descrip- 
tion and his authority to speak on the other's behalf) (CLIFFORD and MARCUS, 1986; DENZIN, 2002). In attempting to speak for the Senegalese "other", there are serious risks of overlooking factors such as the historical and symbolic dominance of the people who are trapped in this social setting and the danger of reproducing the kind of epistemic violence I am trying to escape from. I am only able to describe my encounter with the field and try to be as reflective as possible, while being aware that the politics of the region and the very possibility of encountering my subjects were not only an epistemic concern but also part of the subject-area I was studying. In my view, writing a text and striving to keep it as realistic as possible, are the most infallible way to make all questions surrounding the issue of authority more striking.

Two months of quasi-ethnographic immersion were sufficient to give rise to numerous reflections that I would like to share here and that question both the methodology of inquiry and the concept of digital solidarity. I shall begin with the case of a donation of computers by Company A., via a non-governmental organization B.clic, to Senegal. This study will be restricted to highlighting two significant moments in my investigation: the visit to a rubbish dump and a meeting with Mr G., Head of the National e-Waste Project, whose goal is to fight against the digital divide in Senegal... On both occasions, a sense of real meaning seemed to slip away, yet I felt that something was happening; something which defied what I thought I knew. I was forced to listen anew and try to reflect. Reflexivity is a privileged condition in this narrative, both with regard to method and what I observed and heard. Reflexivity demonstrates how my investigation on digital solidarity in Senegal gradually allowed me to obtain new perspectives and let other voices be heard. Finally, reflexivity shows the radical change I have undergone and my striving to move away from a univocal narrative.

\section{Computer donations: an act of solidarity}

I read the following in an article from a leading French newspaper: "A. France moves to modernize its computer science" (02.02.2007). During a period of downsizing, A. took the opportunity to update its IT equipment and decided to donate a part of its used equipment to B.clic, an association that is fighting against the digital divide problem both in its home region and in Senegal. In this way, A. carried out an act of solidarity in the fight against digital divides and demonstrated its commitment to environmental protection by following the 3Rs (Repair, Reuse, Recycle). The equipment would be reused instead of being thrown away, as A. opened itself up to sustainable development. Moreover, A. published this corporate sponsorship in its financial reports: its environmental balance sheet (required for all listed corporations) was improved and its ecological footprint diminished. The donation was made as a humanitarian gesture and act of solidarity.

The B.clic association is also a recognized instrument of decentralized cooperation. In Dakar, 23 schools (17,000 students) received 500 devices. In an initiative for the transmission of knowledge, the city's ICT service and the Center for Disabled Workers (CHAT) (its partner in the configuration and maintenance of computers) collaborated to create a recycling center in Dakar run by disabled workers. S.clic and CHAT, which operate on a national basis, have set up relaying locally; they provide technical support for installation, teacher training and equipment repairs. On the city's website one can read "2006: S.clic, a concept similar to B.clic was implemented in the Republic of Senegal, 1,500 schools equipped with 30,000 computers." In 2007, B.clic felt honored to be put in the category of "public services for social inclusion and cohesion' by the European Commission, and received the e-Europe award. In addition, the city where B. operates was recognized 'for its efforts to reduce the digital divide while saving the planet' and awarded the 2009 Trophy in the category of Social Responsibility.

From the standpoint of the North, this digital solidarity operation was successful, since it benefited the North as well as the South. Numerous prizes and awards are given for socially humanitarian good deeds. The actors of the North set an example; their act is then relayed by the actors in the South, who equip the country with products at grassroots level. I investigated this exemplary donation, at the M.Beubeuss rubbish dump, where I endeavored to see this digital solidarity donation at the other end of the aid chain.

\section{Taking a walk across the rubbish dump}

After hours of waiting, my small spare water bottle already used up, I travelled in a crowded old minibus, squashed among the passengers and groggy from a lack of oxygen. When I finally arrived at the M'Beubeuss rubbish dump, treading carefully in my highly stain-resistant clothing and with my NGO Enda 
hat perched firmly on my head, I felt indecently rich. Amadou, my guide who only spoke a little, warned me to conceal my camera. We walked along a kind of covered path, strewn with rubbish of all sorts. It opened up a passage through the heaps of waste - at first small mounds which gradually became bigger and bigger. The rubbish dump was immense, and stretched on and on, out of sight.

Smells of burning plastic, mixed with the stench of garbage, grew stronger and stronger. It burned inside my nostrils and eyes, increasing in intensity as we approached the center of the rubbish dump. There were small shacks built of bits of everything from fabrics, plastics, and tires scattered here and there to accommodate small groups of collectors who drank tea sheltered from the sun, but drenched in the fumes and waste. I discreetly took a picture of a small group in the distance but it was not discreet enough. Several men in the group began bawling, and started coming towards Amadou and me. I shouted an apology, and indicated that I had erased the picture, doing my best to get them to understand with hurried gestures. Only when Amadou assured them in Wolof that I had deleted the photo, did calm return. Amadou's apparent anxiety showed how careful I had to be.

I was left feeling more uncomfortable than ever - being the only woman, the only foreigner, the only white person, and only identifiably "rich" person in the area. The experience left me with a raft of questions: how could I close the gap between us? What must I do to avoid spoiling the fragile chance of gaining access to their world? How would "authentic" discussions be possible? I was visibly foreign: my skin color could not be concealed, but I really wanted to avoid being seen as their "other", the Westerner, and to avoid any sign of domination at all costs. I thought that by doing this I might arrange something to be exchanged and not just taken. To carry this out, I had to avoid the kind of "reverse orientalism", where they would see me as a typical exotic 'other' (see ALCADIPANI and REIS, 2010). I felt I had to give the appearance of being at ease, resourceful, and especially to avoid being sophisticated or over-polite.

I realized that what was happening here was partly the product of the policies of Digital Solidarity. Moreover, I knew that one could use words such as sustainable development, social responsibility, capitalism and neo-colonialism to describe what was around me, or even explain everything... but in the reactions of these men, just as in their rage and bitterness and their ways of escaping from their predicament, there was also something which was not reducible to this kind of vocabulary. Such words are too inflated; and to refer to them alone would empty strong, rich signifiers, of their history and sociability (STEWART, 1996). I wanted to see how they merged with the local culture together with its vitality, creativity, desires and fears, and I also wished to incite events and encounters. I had no desire to [return to taking] seek refuge behind my books. I longed to be able to do something about what had happened, then and there.

We turned left and entered a building: the Diom Bok Association. A guard was at the entrance and there was a courtyard in the shade. A man of small stature arrived and Amadou introduced us. The doctor ushered me into a small room and showed me some handwritten spreadsheets detailing the illnesses contracted by people who live and work on the rubbish dump. Then he showed me the examination room: it barely had enough space to house the single bed it contained; and next I was taken to the ward, without a door, and with six beds and six patients. After this, I climbed upstairs to take some photos; the height gave me a panoramic view of one side of the rubbish dump.

I wanted to take photos which would not keep me at a distance from the site and which would also help to convey my readers to the rubbish dump. Being indoors, even taking refuge in this small, medical enclosure, offered me an understanding that no distance could ever provide. It was as if this place was directly expressing itself. This rubbish dump is a place of waste, but it is far from being one of those non-places theorized by Augé (1995). The small medical enclave made me desperately aware that we are all too keen to rely on our concepts and representations to grasp reality, thanks to a "decontaminated" form of knowledge (STEWART, 1996). We take it for granted that it is sufficient to carry out a kind of translation of 'there' to 'here', to show the strange in a familiar light. In addition, we become increasingly prone to issuing abstract and discriminatory judgments. Naming, classifying and coding sanitize the things which present themselves to us at a particular moment, and hence deprive them of their texture and reduce the densities of the places that engulf us. We are quick to restrict our scope to reveal local and singular occurrences by formulating generalizations and abstractions.

We arrived at a place where scavengers were op- 
erating. I saw people working in close proximity to each other, but clearly doing different jobs. Most of them were filling bundles of plastic weighing several kilograms. Others, less numerous and more spread out, collected and sorted different plastic waste material consisting of flexible packaging, hard plastics, and corks scattered about. These men worked in the sun, shrouded in the smoke from the numerous small fires that broke out in the piles of different types of rubbish heaped up in the open air. There were a lot of insects flying around, stinging and annoying us. I was closely following Amadou, who had promised to lead me to places where the electrical and electronic goods were stacked. We strode along and descended the slopes formed by the waste, taking care not to stumble or hurt ourselves. The warmth of the sun, intensified by smoke and fire, the terrible smell from the long line of parked trucks, and the increasing humidity in the air, gave one the impression of being in the midst of a no man's land in a devastated world, that was chaotic, empty, destroyed and haunted by death. I was at once in the center of the world and nowhere at all. This rubbish dump strikingly symbolizes the other face of this world, in a state of perdition.

I work on sustainable development and corporate social responsibility, but why and to what end? This was ridiculous. I was useless, I was nothing and I was lost there in the middle of everything and nothing at the same time. Sustainable development? This immediately seemed a conceptual phantom that was, unrealistic and nothing more than academic jargon: completely wide of the mark. Of what break from reality are you speaking, of the digital or the cognitive world? What a gap there was between this and the reality which was spread out here in front of me! Why had I come to bother these people who survive despite everything, with my petty naive questions from the Western academic world, which despite its good intentions can do very little, if anything at all. My worries filled me with a sense of futility and absurdity and my position disturbed me. "I am ashamed to be here to record these people. How do they see me, and how does my presence affect them: as some kind of misplaced curiosity, or pure courtesy? What can I do here, among these dead deteriorating objects, and, these poor badly-dressed people? Why do they hang around? Why are they fighting? What is this instinct for survival that gives men the will to live whatever the condition of their existence? I will conceal my hugely privileged position. I will take it all in, and observe everything. I will not take any pictures, and I will live as much as possible in the present moment".

I wanted to record my experience, take photographs and collect item, but how could I do this without losing a sense of the place's vitality? How could I replicate what had happened there in front of me? It seemed impossible to capture the experience, make an accurate representation of it or even to give a true description. I could only repeatedly try. I did not need to have the precision of realism; I just wanted be able to evoke the power of the place and the sense of tension. I am unable to do anything more than describe the impressions of my senses, retell the moments that affected me, and think about what moved and affected me. It would be ridiculous to attempt to explain the experience; I feel an urgent need to share it now, to make the experience felt, and to present it rather than attempt to represent it. I was not yet fully aware how much of a political act these descriptions were. The testimonies which elude the representations forced upon them by Northern concepts, and the ability to be aware of 'difference', rather than naming and judging, could have the power to move the order of things. In fact, at that time it was the only thing I felt able to offer.

We arrived in front of a small hut at the top of a mound, and met a man younger than those I had seen before. He was the electronics specialist trained by Enda and the Diom Bok Association. He was the only person in his team who had been trained, and this enabled him to pass on information to his colleagues. It was unclear whether or how much he could speak French. Amadou left to answer a phone call and I was faced with this young man. I made the most of this opportunity to chat with him and obtain information in French. He seemed to understand my language better than he spoke it. To what extent could it be said that we understood each other?

I distrust the concepts that have been designed to provide me with a language for what was happening here, yet it is these same concepts that I want people to tell me about. This is what I was seeking to understand in their language, and their way of living in their world, as well as in this common world of global governance. But I did not speak their language. I wished they could speak to me in my language about my concepts, but no language is isolated from the world it has learnt to express. I had the impression that since that morning I had begun to enter their world, but I knew the road would be long. I had the 
uncomfortable feeling that they understood me more than I understood them.

I soon discovered that because of his training, this person held a key position in the rubbish dump. Since he knew the value of the different components, he held great power. The rubbish dump is also a world of gangs, violence and theft. If I had not come through the Enda Association and been accompanied by Amadou, he would never have talked to me openly. He trusted the NGO Enda. The scavenger explained to me that these large bundles of plastic are sold by weight to corporations. He added that in "the lot" there were one or two rubbish dump workers employed by these corporations in exchange for a "guarantee" of the quality of the plastic sold. This world was not better or purer than ours. It was no less capitalistic or mafialike. It resembled mine. But I had imagined this place could also teach us about solidarity.

Further along, I could see a group of children with some adults. These kids were not playing but were busy collecting things from the ground where there were numerous fires. We arrived at the gathering and Amadou addressed the "head" of the team whom I asked permission to give some candy to the children. The fruit sweets had completely melted and stuck to their wrappers, but the children were unconcerned, as they rushed for their share, smiling and laughing. I felt somewhat relieved to have given them something. It was nothing, yet, they seemed full of joy. Selfishly, I realized that I had made this gesture to alleviate my guilt and feel good about myself, while those children who had nothing, shared the little they had. It made me ponder that it is not just the food that they shared in Senegal; my experience was one of solidarity and of people who gave without counting the cost. I can recall the conviviality of the tea drinking sessions in the evening, when we listened to one another and told stories and shared everything together. Far more than just a description; this was a way of living. Despite being a Toubab (Senegalese word for white foreigners) I was greeted with an incredible warmth that I had not known before. This impression troubled me and still troubles me even when I look back on it now... And yet to what extent do these images represent a kind of Northern "idealization"? How can one avoid taking sides while describing this "reality"? And how can one avoid taking sides when the "reality" is like this?

I then asked if I could record the team leader who welcomed us and shook our hands. He agreed with enthusiasm. His reaction was very supportive; he seemed very happy to be recorded and took our "interview" very seriously. His commitment encouraged me and I sensed he wanted me to be engaged, and not kept at a distance. He hoped I would repeat his words elsewhere, and allow others to know about their world and their activities. What had betrayed this wish on his part to speak? Should I decode him as a structural sign, or view him in an objective way? I realized I still had to find a language to be able to express this in my world.

Being there provided me with a different understanding; an embodied understanding that was territorialized, decentered and de-familiarized. It was as if I could see, touch and perhaps even begin to experience these concepts from another side of the world. I wanted to look at solidarity from the perspective of this rubbish dump, make myself a bit Senegalese, and make a cultural cross-over which would be enough to at least begin to understand the Senegalese faces of solidarity. Of course I knew these were not the only faces of Senegal.

\section{Tipping point}

I had heard that the Senegalese are warm and welcoming, and ready to introduce visitors to the wealth of their country and their culture. It was indeed the case. This particular hospitality that the Senegalese call Teranga (land of welcome) exists and can be felt. Now is the moment to speak about the face of M. G.

"Even though these scavengers earn their living in the informal economy, their main problem is how to retrieve materials of worth: copper, aluminum and other stuff for making stoves and kitchen equipment; it all interests them." I was getting another perspective of the rubbish dump, the "informal sector," in which components would be dismantled on traditional lines and the problems of the people would increase.

G. is the Project Manager for e-Waste S.clic, the national agency which fights the digital divide. The Senegalese President created S.clic (2007) on the basis of the principle that it would be impossible to equip the whole of Senegal with new computers. Thus the struggle to close the digital divide involves providing second-hand equipment. S.clic equips the country's schools and handles everything from customs clearance, refurbishment, equipment, installation, troubleshooting and training. The costs are fully borne by the agency that receives financial support from the 
state. G. drew my attention to the fact that the agency takes special care not to disrupt traditional teaching, so the presence of an empty room is a condition of eligibility for schools which wish to benefit from these donations. In return "...all they ask is that students from time to time use the computers so that these children grow up with computers." These measures against the digital divide by S.clic are, he says, the result of the tripartite partnership between A., B. and S.clic. According to $\mathrm{G}$. it embodies a welcome and recognized cooperation between North and South and public and private sustainable development.

During this interview, I was struck by how much I recognized what was being said. I was in Senegal, but this time I had the impression I was at home. The CSR discourse had pervaded the place. The logic of CSR was here repeated and reincarnated. One spoke to me again about figures, and of praiseworthy and generous concerns, all of which renewed my admiration for these CSR actors. The double-bind situation would be resolved here. Moreover, G. contrasted their work with that of the scavengers. The agency had not yet received its funding, and had not been paid. "I, myself, talking to you have never been paid for this project and I've been involved from the beginning; its all good will. I do it for my country like the other members of the Strategy Committee." His work is also a donation.

But there are moments when things appear, and just happen. These are occasion when one realizes that grand explanatory narratives do not reveal everything (STEWART, 1996); that reality is always richer and resists annexation. Indeed, when I asked if all the equipment donated by A. actually works, the grandiose narrative gave way to an explanatory detail, which filled a gap in the regular CSR discourse. G. replied that the French CHAT only sends functional equipment, but "maybe other organizations..." A study had shown that some schools received computers that were not good, "it's like the case of Bishop Kol Daow who said that once he was sent equipment and unfortunately... all the material was... nothing worked. It was bad! It was unbearable."

Just then the Enda collaborator who accompanied me spoke: "The truth is that there are some who regard Africa as a trash can", and then he retorted, "thereare some computers that may work but they are so dated that you can't do what you want to do with them". The tone was clear. G. seemed to be disturbed that he had not been involved in the discussion. He took over, speaking louder than the collaborator: "At the outset we welcomed P2, but now we don't accept P2. Now, either you send us P3 or P4, and we even tell them we don't actually want P3. It is obsolete. Now you send us P4!"

These comments betrayed another face of this Digital Solidarity. What does this virulent and seemingly uncontrolled discontent mean? I discovered something which resembled humiliation. I tried to put myself in his place... But what would I have felt in such a case? In any event there is something disturbing about the idea of donating second-hand equipment. Receiving rubbish rather than useable equipment was obviously something he had often experienced. Does this mean that donations from the North are a way of getting rid of the equipment we no longer want whilst showing "solidarity" and "responsibility"? Is this not a way of just hiding other practices behind what we call donations? At that moment my own beliefs collapsed, at least in part, and the feelings I had experienced whilst watching the rubbish dump workers and small street traders took on stronger form. The solidarity shown by the North to help develop the south had a dark side. Or is it merely an expression of this double-bind, these paradoxical injunctions, for which there is no simple answer? The CSR narrative falls short of reality because it is unable to mix economic factors with solidarity, equipment with waste, and the discourse of the North with the lands of the South. How can we start to account for this double-bind by only employing a singular narrative and a simple representation, and drawing on concepts that are so far removed from the field, and rely on words that have not encountered the faces and cannot convey the voices of the South?

\section{More than one language}

The case description began with a highly familiar success story, in which the North helped the South, in an exemplary win-win relationship. CSR relies on its accountability, and has become thoroughly dependent on accounts of its activities. It is a way to recount its activities and explain what happens. Yet how can one tell this story in a different way? How can one talk about the life of digital solidarity from the South? Not only is there an imposed story that prevents any other means of accounting for CSR donations, but as will be seen, the very language that is used is a type of monolingualism, which has many implications.

The rubbish dump is one of the blind spots in the all-too-familiar story. It is a place of exclusion where 
the Westerner is forbidden and where the economic, technological, traditional, and religious... all mingle to produce a very specific, yet hardly known, form of life. It is a place that does not easily fit in with the CSR story and would require several languages to be described - in other words, a place of deconstruction.

During the reported interview, the familiar story was repeated, but this time through the mouth of an upper-class, "well-educated" Senegalese man. The story was told by emphasizing the role of the African elite, which is often overlooked in our CSR stories. However, suddenly, a breach occurred in this alltoo- polished discourse. The sense slipped away from common sense, from the right sense. What is never said, what has no place in the right CSR story, was uttered with the brutality of bitter truth: "there are some who take Africa to be a trash can!" Our informant's stance shifted, from being the benevolent partner of a Northern CSR operation, to someone who resists the despicable, even hegemonic Westerner, who has little regard for the Southern other.

It was very difficult to escape from the CSR discourse, but moments like these came as a shock and shifted my attitude to CSR. Now I regard CSR as a way to decribe events in the form of a story, and above all as an imposed language. A donation is always a story (CAILLÉ, 1992); but here, in the course of events, CSR outlines a very peculiar narrative which is rather monotonous, and repeated, nearly unchanged, from one company to another. It is a narrative that cuts into the relational, the historical, the cultural and the collective to shape a one-sided, self-centred heroic story. This story ascribes properties to specific characters (the generous corporation, the population in need, etc.), and omits some key elements (the rubbish dump, the obsolete computers, etc.). Moreover, it is a story that just drifts and threatens to lose sight of the goal of sustainability, where there is a set beginning, end, plot and defined characters who tend to petrify into a kind of monologic retrospective (BOJE, 2008)

The narrative is not only monotonous, but also monolingual and monologic. This single language provides the vocabulary and grammar for what is said and thought and cannot be escaped from. For the Southern countries, the language of CSR is the language of the 'other', which means that it is espoused so that the Northern countries can take part in the process of giving aid while also benefiting from it, and be suspected of this. Of course, as Derrida (1998) puts it, we always speak the language of the 'other': "I have a language, it is not mine". This language forms the basis of our deepest thoughts, but this language is not ours. It has been imposed on us. This means that what is required is not to nostalgically seek another language to replace that of CSR but to remain alert since all that we can do is to try to make something 'happen' to this language.

Monolingualism entails giving voice to Southern countries in CSR standardization committees, which, while desirable, might not make a significant difference to their lives. The elite class who are members of these committees already speak this language and know how to reproduce its rationale. For example, the informant that was quoted above is reproducing the same system as the donor and uses the same language. The "gift" "he" makes to schools (the computers coming from France) is made without any cooperation ("we take care of everything") and he pretends to ask for nothing in return, except symbolic domination and the right to use and believe in the monolingualistic story - suffice it to note that documentation, training, rhetoric, organizational models... all come from the donating country.

The concept of monolingualism also means that those who are unable to speak the language have no voice. Those who live on the rubbish dump are "subalterns", in the sense defined by Spivak (1988). They cannot speak because they do not have the required language. Regardless of what they may try to express, they will not be heard. They do not have access to proper media and their "voice" is simply reinterpreted inside the language of the 'other'. In short, they have no voice because they are not a part of the story (and hence of history?).

CSR monolingualim has many effects. Just two will be mentioned here - the first concerning accountability. In the CSR language game, everybody has to account for their actions, whether as giver or receiver, in terms of numbers and quantities, and this constitutes a very specific kind of subject. The quantitative side of accountability is given greater prominence than meaning, relations, belongings and expression. As Kamuf (2007) pointed out, we need a counterability to accountability to reopen the "accounts" of ourselves at the richer and more respectable other end of the spectrum - allowing for times when stories are recounted and language produced. A second feature of this language is that it ascribes meaning to certain actions that are not discussable. For example, sending 
computers to a Southern country is unquestionably regarded as making a gift (In the French language used by all the institutional characters of the story, donation and gift is the same word). The doublebind situation has no word inside the CSR language. The fact that many of those so - called gifts are obsolescent products, or go directly to the rubbish dump, is irrelevant. Equally irrelevant is the charge the company would have had to pay to dispose of these materials or the profits accrued by the company in terms of improving its image. As Derrida (1992) stated, a pure gift should be devoid of any selfish calculation or interest and offered without any expectation of gain - either economic or narcissistic. Even if such a pure gift does not exist, what is here designated as a gift or donation can be deconstructed, or at least suspected. If a good deal of the donated computers go directly to the rubbish dump, then what does it mean to "give" rubbish? If the receiver does not really have any choice in the matter when receiving the donation, what kind of counter-gift is expected? As Godbout (2000) argues, it is not just through markets that the dominated markets forfeit their souls, but also by not making a gift in return.

To understand the double-bind situation and make something happen to the CSR language, we must become more sensitive to certain "double entendres", which Derrida taught us to recognize. By donating computers, the North says: "you are gifted"; i.e. you have to accept the gift and become indebted. But one might also hear: you are talented, you are able to create your language (inside or outside of mine). In the same way, being socially responsible means on the one hand "I can prove that I have complied with the correct standards and shown commitment", but might also mean "I am willing to address the questions from the South"; i.e. I hear the voice and wishes of the 'other' and will respond regardless of the norms. Derrida (2000) showed that complete answers to the questions of the foreigner could not be governed by a set of laws.

Far from being complete, the task of understanding CSR from a post-colonial perspective and of criticizing the language it imposes, has only just begun. As a matter of fact, in this research project, I have not been seeking a counter narrative (MUTUA and SWADENER, 2004). I only provide an account of how my encounters caused me to become "upset"; how they concerned and touched me, by confronting me with the unfamiliar, and overturning my sense of self- sufficiency. In this way, they allowed me just to tell my experiences. The kind of "I " described by Butler (2005) is incapable of irresponsibility.

It was in the course of incidents, meetings and arguments that I began to understand what CSR is and its effects on this place. My head was spinning from the smell of waste, two informants were arguing about their interpretations, and I felt really European when I was affected by the European discourse. Even words like North and South started to have little meaning away from a map. In the first steps towards deconstructing the monolingualism of CSR, we feel that we are constrained by our ways of speaking but this is the precondition for more than one language to come.

I needed this whole journey and all these experiences and reflexivity, as well as this long period of radical change of my feelings and insights, so that I could escape from this imposed story, with its single language, and inability to think outside of its inherent structure. As Saïd (1993) said: colonial discourses are still shaping the colonized and colonizing subjects long after the liberation of their countries.

We need more voices, languages, and stories. We need others who come from Africa, Latin America, South Asia, and subaltern regions of the North. But how can we listen to these voices without betraying them? How can we join our voices in unison, by speaking to one another, and starting to understand each other so that we can reach a common understanding of solidarity?

\section{NOTE OF APPRECIATION}

The authors warmly thank Kim Tsai for her invaluable help

in bettering the language and style.

\section{REFERENCES}

AGUILERA, R; RUPP, D; WILLIAMS, C; GANAPATHI, J. Putting the $s$ back in corporate social responsibility: a multilevel theory of social change in organizations, Academy of Management Review, v. 32, n. 3, p. 836-63, 2007.

ALCADIPANI, R; REIS ROA, A. O pesquisador como o outro: uma leitura pós-colonial do 'Borat' brasileiro, 
RAE-Revista de Administração de Empresas, v. 50, n. 4, p. 371-382, 2012

AUGÉ, M. Non-places: introduction to an antbropology of supermodernity, London: Verso, 1995.

BATESON, G. Steps to an ecology of mind: collected essays in anthropology, psychiatry, evolution, and epistemology. Chicago: University Of Chicago Press, 1972.

BOJE, D. Storytelling organizations. London : Sage Publications. 2008.

BRUNEL, S. Les ambiguïtés du développement durable. In: Sciences humaines, Sauver la planète ?, hors série, n. 49, jul-ago, 2005.

BRUNDTLAND, Our common future, Oxford: Oxford University Press, 1987.

BUTLER, J. Giving an account of oneself, New York: Fordham University Press, 2005.

CAIllé, A. L'esprit du don, Paris: La Découverte, 1992.

CAMPELL, J. Why would corporations behave in socially responsible ways? an institutional theory of corporate social responsibility, Academy of Management Review, v. 32, n. 3, p. 946-967, 2007.

CLIFFORD, J; MARCUS, G. Writing culture: the poetics and politics of ethnography. Berkeley: University of California Press, 1986.

DENZIN N. Confronting ethnography's crisis of representation, Journal of Contemporary Ethnography, v. 31, n. 4, p. 482-490, 2002.

DERRIDA, J. Given time: I. Counterfeit Money, Chicago \& London: University of Chicago Press, 1992.

DERRIDA, J. Monolingualism of the other; or, the prosthesis of origin. Stanford: Stanford University Press, 1998.

DERRIDA, J. Of hospitality: anne dufourmantelle invites $j$. derrida to respond. Stanford: Stanford University Press, 2000.

DERRIDA, J. Globalization, peace, and cosmopolitanism. in negotiations: interventions and interviews 1971-2001, ed. E. Rottenberg. Stanford, CA: Stanford University Press. 2002. p.371-386.

DOYLE, T. Sustainable development and agenda 21: the secular bible of global free markets. v. 19. Third World Quarterly. London: Routledge. 1998. p. 771-786.

FREEMAN, RE. Strategic management: A stakeholder approach. Boston: Pitman. 1984. 276 p.

GODBOUT, J., Le don, la dette et l'identité : homo donator versus homo oeconomicus, Paris : La Découverte, 2000

KAMUF, P. Accounterability. Textual Practice, v. 21, n. 2, p. 251-266, 2007.

MANCEBO, F. Le développement durable en question(s). In: Cybergeo, Epistémologie, Histoire, Didactique. Available at : http://www.cybergeo.eu/index10913.html. Access 01.11.2009.

MARENS, R. Destroying the village to save it: corporate social responsibility, labour relations, and the rise and fall of american hegemony, Organization, v. 17, n. 6, p. 743-766, 2010.

MATTEN, D; MOON, J. Implicit and explicit CSR: a conceptual framework for a comparative understanding of corporate social responsibility, Academy of Management Review, v. 33, n. 2, p. 404-24, 2008.

MORICEAU, J. L. Faceless Figures: is a socially responsible decision possible? In: PESQUEUX, Y.; BONNAFOUSBOUCHER, M. Stakeholder Theory: A European Perspective. New York: Palgrave MacMillan, 2005, p. 89-103.

MUTUA K; SWADENER BB. Decolonizing research in cross-cultural contexts: critical personal narratives. Albany New York: SUNY PRESS. 2004. 283 p.

PESQUEUX Y. Pour une évaluation critique de la théorie des parties prenantes. In BONNAFOUS-BOUCHER, M., PESQUEUX, Y, Décider avec les parties prenantes, Paris: La Découverte, 2005, p. 21-39.

PAULA SOARES, G. M. Responsabilidade social corporativa : por uma boa causa!?, RAE-eletrônica, v. 3, n. 2, 2004. Available at: http://rae.fgv.br/rae-eletronica/ vol3-num2-2004/responsabilidade-social-corporativa-porboa-causa. Access 01.11.2009. 
PESQUEUX Y. Genèse de la responsabilité sociale de l'entreprise. HALSHS archives ouvertes, 2010.

SAID, E. Culture and imperialism. New York: Vintage, 1993.

SCHROEDER, P.T ; SCHROEDER, I. Responsabilidade social corporative: limites e possibiliades, RAE-electrônica, v. 3, n. 2, art. 1, 2004. Available at: http://rae.fgv.br/rae-eletronica/vol3-num1-2004/responsabilidade-social-corporativalimites-possibilidades. Access 01.11.2009.

SOLÉ A. Créateurs de monde, Monaco: Editions du Rocher. 2000.

SPIVAK, GC. Can The Subaltern Speak? In: NELSON C; GROSSBERG, L. Marxism and the Interpretation of Culture. Urbana/Chicago: University of Illinois Press. 1988, p 271-313.

STEWART K. A Space on the Side of the Street. New Jersey: Princeton University Press, 1996. 264 p.

STEWART K. Ordinary Affects, Durham NC: Duke University Press, 2009. 133 p.

UNCTAD. Measuring ICT for Development. Available at: http://www.unctad.org/templates/Page. asp?intItemID=4565\&lang=1, 2008. Access 10.04. 2011.

WAILES, N; MICHELSON, G. The Transfer of Management Ideas to a Western Periphery: The Case of Corporate Social Responsibility in Australia, International Journal of Management and Organization, v. 38, n. 4, 2009, p. 100-118.

WATZLAWICK, P; BEAVIN, J. H; JACKSON, M.D. Pragmatics of Human Communication, New York: WW. Norton, 1967. 